\title{
Factors Influencing the Implementation of Activity-Based Costing: A Study on Malaysian SMEs
}

\author{
Sudhashini Nair ${ }^{1} \&$ Xin $\operatorname{Tan}^{1}$ \\ ${ }^{1}$ Faculty of Business, Accounting and Management, SEGi University, Kota Damansara, Selangor, Malaysia \\ Correspondence: Sudhashini Nair, Faculty of Business, Accounting and Management, SEGi University, Kota \\ Damansara, 47810, Petaling Jaya, Selangor, Malaysia.
}

Received: June 12, 2018

doi:10.5539/ibr.v11n8p133

\author{
Accepted: July 19, $2018 \quad$ Online Published: July 25, 2018 \\ URL: https://doi.org/10.5539/ibr.v11n8p133
}

\begin{abstract}
Literature has indicated that factors such as--the external environment, cost saving mechanisms, user attitude and company size--may have an effect on the implementation of activity-based costing (ABC). Furthermore, literature has revealed that there is still lack of research on the effect of these factors on the implementation of $\mathrm{ABC}$ among small and medium sized enterprises (SMEs) in Malaysia. As such the aim of this research is to test the relationships of these factors on the implementation of $\mathrm{ABC}$ among SMEs in Malaysia with the aim of contributing to existing research on the $\mathrm{ABC}$ system in the area of management accounting. A total of 200 respondents participated in this research. The results of the study revealed that all four factors; the external environment, cost saving mechanisms, user attitude and company size have significant relationships with the implementation of ABC among SMEs in Malaysia.
\end{abstract}

Keywords: company size, cost saving mechanisms, implementation of activity based costing, the external environment, user attitude

\section{Introduction}

According to Cooper and Kaplan (1991), Activity-Based Costing (ABC) is a management accounting technique that assigns cost to products and services based on the resources that these products and services consumed hence, $\mathrm{ABC}$ is an approach to the costing and monitoring of activities, which involves tracing resources consumption and costing of final output, thus focuses attention on cost drivers; the activities that cause cost to increase. As the manufacturing sector experiences technological advancement in automation and robotics, changes have been taking place in the manufacturing cost structure which led to the shift from traditional volume based costing to the ABC method (Zhang \& Isa, 2010). Furthermore, besides innovation and increased technology, the globalisation of products and services have created a competitive business environment hence, requiring data to be identified accurately and must be relevant to the cost and performance of the organisation's activities, thus the importance of the ABC method in today's environment (Ismail \& Reddy, 2017). Initially, the adoption of $\mathrm{ABC}$ was slow due to the high expenditure involved in employing and sustaining the $\mathrm{ABC}$ system, however the $\mathrm{ABC}$ system has been used widely in countries such as the United States of America (USA) (Brierley, 2009), the United Kingdom (UK) (Al-Omiri \& Drury, 2007), and Canada (Quinn, Elafi, \& Mulgrew, 2017). This costing system has gained international recognition in not only developed countries but emerging economies such as China (Anderson \& Young, 1999), Taiwan (Lou, Wang \& Lan, 2017) and Malaysia (Ahmad, Teng, \& Zabri, 2015; Maelah \& Ibrahim, 2007) as they gain competitive advantages in the pursuit of globalizing their economies.

There are four generations of ABC evolving from 1987 to 2010. Firstly, ABC appeared as an accurate costing system, as cost and profit drivers and as a tool used for activity-based management. In the second generation, it was being applied in a multi-industry; used as an extended value chain and as a predictive model in process analysis. In 2000, during the third generation of $A B C$, it became a sustainable enterprise system in many industries. Lastly, it provided integrated performance management solutions and was used as an analytical tool. $\mathrm{ABC}$ as such has been evolving drastically over more than two decades; starting from an early experiment in costing, $\mathrm{ABC}$ eventually appeared as a tool for profit improvement (Hooper, Tsamenyi, Udin, \& Wickramasinghe, 2009). Some of the benefits of the ABC system include better job allocation of overheard expenditure as it does not group costs that are spread out across many different activities, $\mathrm{ABC}$ also does a better 
job of separating the cost of idle capacity from the true cost of producing a product and finally, ABC provides management with a way to have continuous improvement, help to identify cost and profit enhancement opportunities subsequently, leading to better company profitability (Kocakulah, Foroughi, Stott, \& Manyoky, 2017).

Although the implementation and success of $\mathrm{ABC}$ can be seen in multinational companies (MNCs) such as automotive manufacturers; General Motors, Chrysler and Ford Motors as well as food processing companies such as Nestle and Mondelez and, waste recycling company such as Safety Kleen (Beheshti, 2004; Mahal \& Hossain, 2015; Zhang \& Isa, 2010), SMEs have also started implementing the ABC method especially in the wine industry and in cook-shops (Finke \& Businska, 2011). Despite the fact that the ABC method can be costly and time consuming, an SME's size and business structure allows them to be flexible and innovative, allowing them to incorporate the $\mathrm{ABC}$ system into their business to gain a competitive advantage as they expand their business (Gunasekaran, Marri \& Grieve, 1999). In most countries including Malaysia, SMEs make up the majority of the business population, hence they play an important role in generating economic growth (Ahmad, 2012; Ahmad, 2014; Nair \& Yee, 2017). SMEs make up 95 percent of enterprises worldwide, accounting to $67 \%$ of employment in private sector and 52\% private sector value added (Kocakulah et al., 2017). Ahmad et al. (2015) stated that more than $90 \%$ of the total manufacturing output (Gross Domestic Product and exports) in Malaysia was generated by SMEs. The Malaysian government has enacted various policies to promote SME development and improve performance by providing financial assistance and training in technical aspects (Ahmad, 2012). Furthermore, SMEs have taken practical steps in implementing management accounting practices (MAPs) such as ABC to improve accuracy of costing, pricing and planning (Hall \& McPeak, 2011). Although $\mathrm{ABC}$ has received wide spread acceptance, there is still lack of information on the factors affecting the implementation of $\mathrm{ABC}$ among SMEs especially in Malaysia.

The appraisal of previous studies has indicated that factors such as the external environment, cost saving mechanisms, user attitude and company size, may have an effect on the implementation of ABC in SMEs (Ahmad, 2012; Ahmad et al., 2017; Chand \& Dahiya, 2010; Nandan, 2010; Sohal \& Chung, 2011). The external environment is one of the important factors that promoted the usage of ABC in SMEs as market competition can play an important role in encouraging SMEs to use the ABC system. Although SMEs may not need comprehensive MAPs, nevertheless, SMEs play an important role in the economy, they face similar forms of complexity and may be prone to failures, and hence better resource allocation together with a timely, accurate and reliable costing method is needed (Nandan, 2010). As such, SMEs use ABC for accurate cost calculation and competitive pricing (Ahmad, 2012, Nair \& Yee, 2017). Furthermore the implementation of the ABC system may also be the result of companies incorporating their objective of gaining competitive advantage as SMEs continue to grow bigger. Furthermore the cost management of $\mathrm{ABC}$ also concentrates on target costing and searches for possibilities to improve customer satisfaction, improve productivity and maximize profit.

In terms of $\mathrm{ABC}$ as a cost saving mechanisms, in India, SMEs that explored the usage of MAPs such as ABC found that the firms' cost reduction and quality improvement led to the success of ABC (Chand \& Dahiya, 2010), Furthermore, the use of the $\mathrm{ABC}$ system has allowed SMEs to achieve cost saving and transparency in their operations especially when these companies strive to attain competitive advantage in the age of globalization (Kocakulah et al., 2017).Another important factor that may contribute to the implementation of ABC in SMEs is the user attitude. Many users have inconsistent opinions about the ABC system in SMEs, due to lack of education and awareness. Nevertheless, with the government support and training, the user attitude towards the implementation of ABC may become positive (Yapa \& Konchange, 2012). Research has indicated that together with the management commitment and an $\mathrm{ABC}$ project team, a user attitude was vital to the successful execution of the ABC system (Sohal \& Chung, 2011).Furthermore, to create awareness of the ABC system, user attitude and personal characteristics may also have an influence in the employment of the ABC system in SMEs (Machado, 2012).

Finally another factor that may have an effect on the implementation of ABC in SMEs is the company size. Larger firms may have greater resources to allow for the successful implementation of MAPs such as the ABC system (Ahmad, 2012; Nair \& Yee, 2017). As a company becomes bigger, there would be greater amounts of information to be handled, thus $\mathrm{ABC}$ system becomes appropriate in accurate representation of how activities perform the creation of a product or service. Furthermore, activity related information would be greater in large companies as there are greater resources leading to an effective use of $\mathrm{ABC}$, nevertheless, $\mathrm{ABC}$ would be beneficial and valuable to SMEs if implemented and used correctly under the right conditions (Baird, Harrison \& Reeve, 2004). 
The appraisal of previous studies has indicated that the external environment, cost saving mechanisms, user attitude and company size have been commonly cited as factors that may affect the implementation of ABC among SMEs. There is still limited research examining the impact of these factors with the implementation of ABC among SMEs in Malaysia, hence this study aims to study the relationship of these factors with the implementation of $\mathrm{ABC}$ among SMEs in Malaysia, subsequently providing new evidence to existing research on the implementation of the $\mathrm{ABC}$ method among SMEs.

\section{Literature Review and Hypotheses Development}

\subsection{Relationship between the External Environment and the Implementation of Activity-Based Costing}

The external environment is defined as forces outside the organization such as market competition and perceived environmental uncertainty that can influence an organization's day to day activities (Chenhall, 2007). Previous research by Ríos, Colomina, and Rodríguez-Vilariño (2014) found that there is a growing awareness on the importance of the ABC system in SMEs as they become competitive in the era of globalization. Furthermore, it was found that the ABC system was used as a weapon to cushion SMEs from a volatile business environment and subsequently improved their survival in the business (Kraus, Harms \& Schwarz, 2006). Competition is thus an external factor that lead to SMEs to use sophisticated MAPs such as the ABC method (Zhang \& Isa, 2010). According to the research by Elhamma and Zhang (2013) in Morocco using a sample size of 48 industrial enterprises with $48 \%$ consisting of SME and 52\% consisting of large firms, it was found that the influence of the external environment such as market competitiveness resulted to the implementation of ABC. Furthermore Byrne (2011) found that the level of the external environment was found to be a contributing factor in the implementation and success of the $\mathrm{ABC}$ system. As such, the following hypothesis is developed:

H1: There is a significant positive relationship between the external environment and the implementation of activity- based costing in Malaysian SMEs.

\subsection{Relationship between the Cost Saving Mechanisms and the Implementation of Activity-Based Costing}

Cost saving mechanisms are defined as a tools used by a company to save money through the reduction of expenses associated with the activities of the company. SMEs intention to save cost could be a leading factor for the implementation of ABC. Kulmala, Kajuter, and Valkokari (2007) found that although SMEs in general did not focus on cost management tools nevertheless, MAPs such as the ABC system have allowed SMEs to better understand the links between activities, operating results and network cost, hence increasing cost awareness and prompting the use of the ABC method among SMEs. In the research by Cagwin and Bouwman (2002) on the improvement of financial performance with the use of the $\mathrm{ABC}$ system, the authors found that the usage of other cost saving mechanisms such as Total Quality Management (TQM) and Just in Time (JIT) used together with ABC contributed to the successful implementation of ABC. Furthermore, James's (2013) study in Jamaica on commercial and merchant banks found that the perceived ability of $\mathrm{ABC}$ to assist in cost control and saving allowed for the implementation of $\mathrm{ABC}$. As a result, the following hypothesis was proposed:

H2: There is a significant positive relationship between cost saving mechanisms and the implementation of activity-based costing in Malaysian SMEs.

\subsection{Relationship between the User Attitude and the Implementation of Activity-Based Costing}

User attitude is defined as an individual's positive or negative feeing associated with performing a specific behavior (Ajzen \& Fishbein, 1975). Briciu and Căpuşneanu (2010) stated that the emphasis by management to change user attitude and encourage employees to learn and grow for the purpose of self-improvement would lead to the successful implementation of the ABC system. According to Xu (2012), lack of cooperation within the organization may have an effect on the implementation of $\mathrm{ABC}$. The author also found that a good user attitude could possibly change the adoption and correct use of the ABC system. According to Khozein and Dankoob (2011), user denial is one of the reasons affecting the implementation of ABC in their organisations. In the study by Dubihlele and Rundoro (2014) on 149 SMEs in South Africa, it was found that user attitude; managerial commitment was a precursor to the implementation of ABC of SMEs in South Africa. As a result, the following hypothesis was developed:

H3: There is a significant positive relationship between user attitude and the implementation of activity-based costing in Malaysian SMEs.

\subsection{Relationship between the Company Size and the Implementation of Activity-Based Costing}

Company size is defined as "the number of employees in the organization, however organization size can also be measured by the paid up capital of the organization" (Nair \& Yee, p. 178). Size has been found to have an 
important factor affecting the implementation of $\mathrm{ABC}$ as research has found that companies with greater resources and complex administration systems have a better success rate with the implementation of $\mathrm{ABC}$ (Al-Omiri \& Drury, 2007). In the research by Pokorná (2016) on 548 Czech medium and large companies, it was found that size moderately affected the impact of $\mathrm{ABC}$ on financial performance. Finally, according to the research by Elhamma (2012) on 62 firms in Morocco, it was found that the firm size positively influenced the use and successful implementation of ABC. As such, the hypothesis below was postulated:

H4: There is a significant positive relationship between company size and the implementation of activity-based costing in Malaysian SMEs.

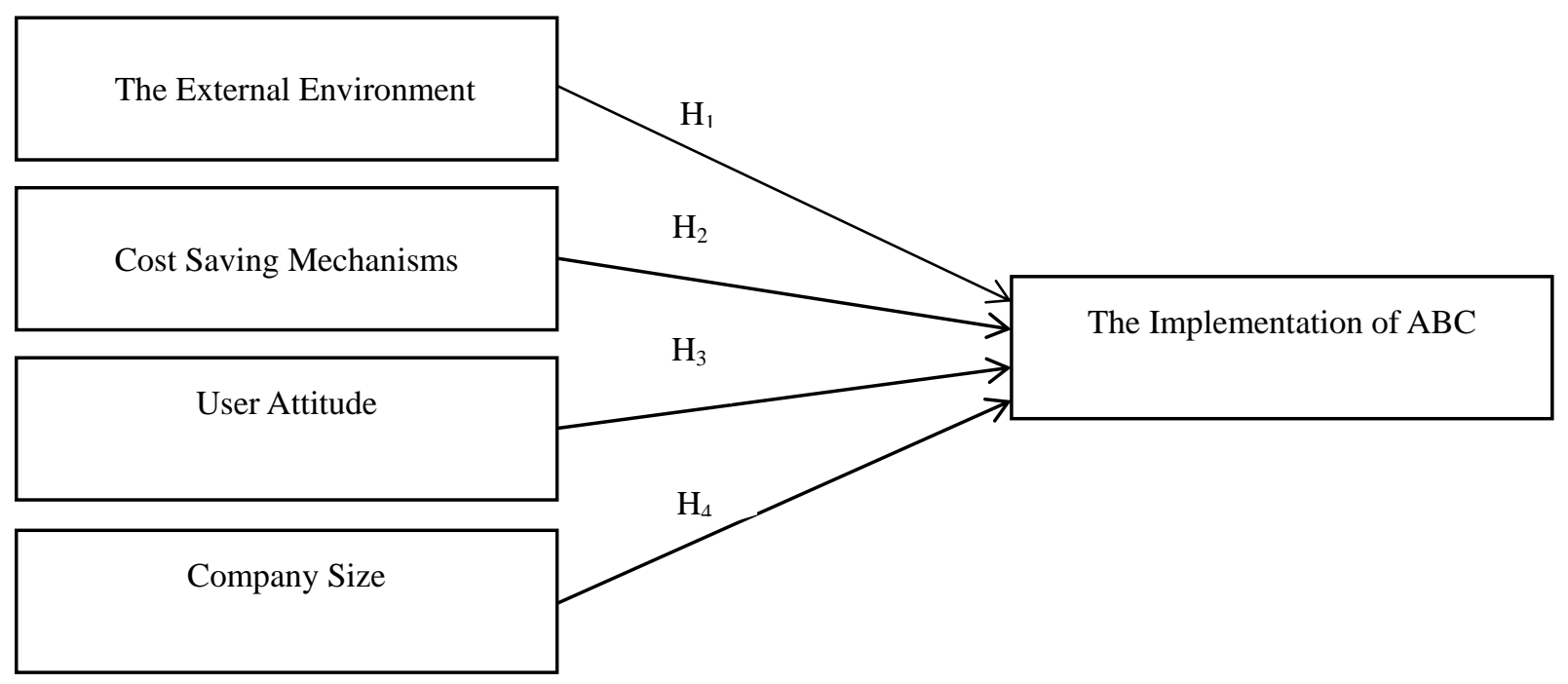

Figure 1 shows the research model and the related hypotheses

\section{Research Method}

The deductive approach using explanatory research was applied in this study to establish the relationships between the variables (Sekaran, 2006). The study focused on SMEs in the manufacturing industry in Selangor Malaysia due to the high concentration of SMEs in this state compared to all the other states in Malaysia (Department of Statistics Malaysia, 2016). The sample was collected using a quantitative approach using non-probability sampling method; purposive sampling technique. Data was collected from 200 respondents from SMEs in Selangor Malaysia who have begun implementing the ABC method and are registered under the SME Corporation of Malaysia. These companies are in the process of forming a team of $\mathrm{ABC}$ implementation which according to Faudziah and Rababah (2011) are companies that have determine project scope and objectives; have design training and workshops, have collected data, have analyzing activities, cost drivers and have organizational members commitment to use ABC.

A self-administered questionnaire was used to collect data from 200 respondents who held financial executive positions in these SMEs who are involved in the $\mathrm{ABC}$ implementation of their respective organisation. The questionnaire in this study was separated into two sections. The first section required the respondents' to provide information with regards to the number of full time employees, average annual sales and business duration of their organization followed by the respondents' education level. The second section of the questionnaire utilized several measures. The variables; implementation of $\mathrm{ABC}$ and company size was measured using a five item scale adapted from Elhamma (2012). As for the external environment, a five item scale was adapted from Hansen and Van der Stede (2004). A five item scale for cost saving mechanisms was adapted from Cagwin and Bouwman (2002). As for user attitude, a five item scale was adapted from Ismail and King (2007). A 5-point Likert scale ranging from (1) "Strong Disagree" to (5) "Strongly Agree" was used to measure the variables in this study. The data from this study was computed using SPSS.

\section{Data and Result Analysis}

A reliability test was conducted and it was found that reliability test of the each of the variables in this study was more than 0.80. (Hair, Black, Bablin, \& Anderson, 2010; Sekaran, 2006). In additional to this, normality test was done using $\mathrm{z}$-score calculation. The result of the normality test of 0.756 was within the acceptable range of -3.29 $<\mathrm{Z}>3.29$. Furthermore, the graph and histogram of this study was also normal. Moreover, a linearity test was conducted to test the relationship of every independent variable to the dependent variable. The graphical method 
was used in this research to evaluate linearity; Ii was found that the study produced randomized pattern indicating that the linearity assumption was met. For the descriptive data, Table 1 shows the profile of respondents' organisation.

\subsection{Profile of Respondents' Organisation.}

Table 1. Number of Full Time Employees, Average Annual Sales, Business Duration and Education Level of Respondents

\begin{tabular}{llll}
\hline Types & Categories & Frequency & Percent \\
\hline Number of Full time employees & 5-75 (small) & 70 & 35 \\
& $75-200$ (Medium) & 130 & 65 \\
Average Annual Sales & RM0-RM300,000 & 14 & 7 \\
& RM300,000-RM15 million & 78 & 39 \\
& RM 15 million-RM50 & 90 & 45 \\
& Million & & 9 \\
Business Duration & RM50 million and above & 18 & 10 \\
& $<5$ years & 20 & 25 \\
& 5 -10 years & 50 & 45 \\
Education Level of Respondents & 11-15 years & 90 & 20 \\
& Undears & 40 & 23.5 \\
& Undergraduate & 47 & 45.0 \\
& Postgraduate & 90 & 28.0 \\
\hline
\end{tabular}

\subsection{Pearson Correlation Test}

The Pearson Correlation ( $r$ ) test was used to measure the strength and direction of a linear relationship between two variables. The value of $(r)$ is always between +1 and -1 . The results of the correlation test shows that the external environment was 0.717 , cost of saving mechanism was 0.752 , user attitude was 0.710 and company size was 0.699 . The result of the correlation test indicates that the external environment, cost saving mechanism and user attitude has a strong positive correlation with the implementation of $\mathrm{ABC}$ while, company size has a fairly high positive correlation with the implementation of ABC. The Pearson Correlation test results are shown in Table 2.

Table 2. Pearson Correlation Test

\begin{tabular}{llcccccc}
\hline & & $\begin{array}{l}\text { Implementation } \\
\text { of Activity Based } \\
\text { Costing }\end{array}$ & $\begin{array}{l}\text { The External } \\
\text { Environment }\end{array}$ & $\begin{array}{l}\text { Cost Saving } \\
\text { Mechanisms }\end{array}$ & User Attitude & $\begin{array}{l}\text { Company } \\
\text { Size }\end{array}$ \\
\hline $\begin{array}{l}\text { Implementation of } \\
\text { Activity }\end{array}$ & $\begin{array}{l}\text { Pearson } \\
\text { Costing }\end{array}$ & 1 & .717 & .752 & .710 & .699 \\
& $\begin{array}{l}\text { Correlation } \\
\text { Sig. } \\
\text { tailed) } \\
\mathrm{N}\end{array}$ & & & .000 & .000 & .000 & .000 \\
\end{tabular}

\subsection{Multiple Regression Analysis}

In order to examine the research hypotheses, the Multiple Regression test was conducted for the general purpose of studying the association among the independent variables and the dependent or criterion variable ((Sekaran, 2006).). This study produced an $R$ Square value of 0.816 . This means that $81.6 \%$ of the total variance in the dependent variable was explained by the total independent variables in the study, as such the higher the $\mathrm{R}$ square value, the stronger the relationship between the variables in the research. Furthermore, the value of Durbin Watson must be in the range of 1 to 3. In this research, the value of Durbin Watson was 1.781 which is in the range of 1 to 3 . This shows that there is no autocorrelation problem among the residuals and thus the assumption of homoscedasticity was satisfied. Table 3 shows the model summary.

Table 3. Model Summary

\begin{tabular}{llllll}
\hline \multicolumn{2}{l}{ Model Summary } \\
\hline Model & R & R Square & Adjusted R Square & Std. Error of the Estimate & Durbin-Watson \\
\hline 1 & $.816^{\mathrm{a}}$ & .667 & .660 & .45669 & 1.781 \\
\hline
\end{tabular}

The model is fit to use for further analysis if the significant value is equal or below than 0.05 . Based on the ANOVA analysis, the results of significant value is 0.000 which is below 0.005 , hence there is a significant relationship between each of the independent variable (the external environment, cost saving mechanisms, user attitude, company size and the dependent variable (implementation of $\mathrm{ABC}$ ). The F-statistic was 97.482 indicating that the model of this study is strongly significant. Besides that, the $\mathrm{F}$ value indicates that the variance 
is not totally accounted for by possibility. Table 4 below shows thee analysis of variance (ANOVA).

Table 4. Analysis of variance (ANOVA) in this study

\begin{tabular}{lllllll}
\hline ANOVA $^{\mathbf{a}}$ & & & & & \\
\hline Model & & Sum of Squares & Df & Mean Square & F & Sig. \\
1 & Regression & 81.327 & 4 & 20.332 & 97.482 & $.000^{\mathrm{b}}$ \\
& Residual & 40.671 & 195 & .209 & & \\
& Total & 121.998 & 199 & & & \\
\hline
\end{tabular}

The results of the coefficients shows that coefficients between the independent variables (the external environment, cost saving mechanisms, user attitude, company size and the dependent variable (implementation of $\mathrm{ABC}$ ) are significant. All below 0.05. This indicates that the proposed research hypotheses can be accepted. The results if coefficients can be seen in Table 5 and the summary of the hypotheses results are in Table 6 .

Table 5. Results of the coefficients

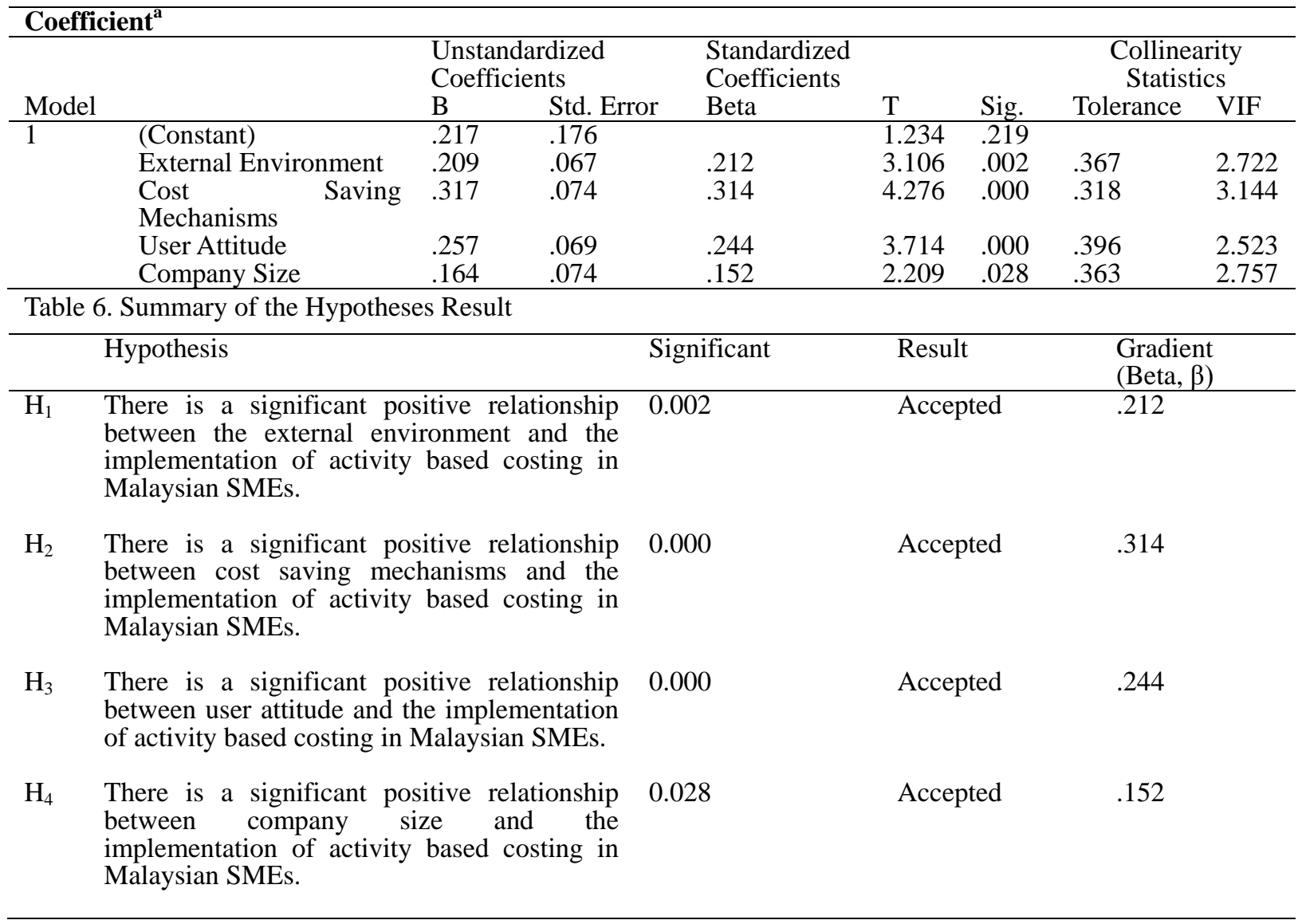

\section{Discussion and Conclusion}

This research was conducted to study the relationships of the external environment, cost saving mechanisms, user attitude and company size on the implementation of $\mathrm{ABC}$ among SMEs in Malaysia. The research findings revealed that all four factors have a significant positive relationship on the implementation of ABC among SMEs in Malaysia. In this study, the external environment produced a significant positive association with the implementation of ABC as per previous studies (Elhamma \& Zhang, 2013; Kraus et al., 2013; Rios et al., 2014; Zhang \& Isa, 2010). The findings would hopefully create awareness among the Malaysian Government, the accounting profession as well as public and private sector that appropriate policies should be developed and implemented to encourage SMEs to use factors such as the external environment to allow SMEs to stream line activity outputs when competing with other business units/rivals.

Cost saving mechanisms has a positive significant association with the implementation of $\mathrm{ABC}$ similar to the findings of Cagwin and Bouwman (2002) and James (2013). SMEs should be encouraged to incorporate cost saving techniques like JIT and TQM to improve the success of the ABC system to allow for continuous improvement. The TQM technique could be used to support $\mathrm{ABC}$ in generating data of value-added and non-value-added quality related activities, hence allowing for the detection of improvement possibilities in 
products and services of SMEs. As with the JIT system which reduces the amount of money invested in inventory of raw material and finished goods, the ABC system would allow strict control to be exercised on certain materials that have higher value and also reduce the cost of storage.

As per previous research, this study has also found that user attitude has a positive significant relationship with the implementation of ABC among SMEs (Khozein \& Dankoob, 2011; Dubihlele \& Rundoro, 2014). Human capital development is essential for SMEs to provide them with the necessary knowledge, skills to employees to change user attitude and allow for a better usage of the ABC system in SMEs. Lastly, company size has a positive significant association with the implementation of ABC in SMEs similar to the findings of Elhamma (2012) and Pokorná (2016). As a company size grows and diversification takes places, it is important to implement $\mathrm{ABC}$ to better understand both customer and product profitability. According to Devine, Lammert and O'Clock (2005), it was proposed that the extension of the ABC system such that assets are also assigned to activities is with the aim of allowing managers to analyse customers and products with the same attention to return on investment that has been used for evaluating business units. Through this a growing company size company size would have a better impact on the implementation of $\mathrm{ABC}$ among SMEs.

There are a few limitations in this study, firstly the study could have included other states in Malaysia especially Johor and Penang which has the second and third highest number of SMEs in Malaysia (Department of Statistics Malaysia, 2016). The study may have also included other internal or external factors that may affect the implementation of $\mathrm{ABC}$ among SMEs in Malaysia. As such, recommendations are proposed to future researchers. Firstly it is suggested that future research should have a broader based population that includes other states in Malaysia. Also other factors such as leadership and technology advancement should be included as these factors may also have an effect on the implementation of ABC in SMEs (Khozein \& Dankoob, 2011).A longitudinal study to examine the importance of these factors on the implementation of ABC in SMEs is also recommended. The results of this research will contribute to current studies on factors that affect the implementation of $\mathrm{ABC}$ in SMEs. The results would hopefully influence the government and policy makes that these factors are important to the implementation of ABC among SMEs in Malaysia. Furthermore, the researchers believe that the results of this study will allow economist and accountants to gain new knowledge on the factors that affect the implementation of $\mathrm{ABC}$ on SMEs.

\section{References}

$(\mathrm{ABC})$ in the financial sector in Jamaica. International Journal of Business and Social Research (IJBSR), 3(7), $8-18$.

Ahmad, K. (2012). Factors explaining the extent of use of management accounting practices in Malaysian medium firms. ASEAN Entrepreneurship Conference 2012. https://doi.org/10.1108/JSBED-04-2012-0057

Ahmad, K. (2014). The adoption of management accounting practices in Malaysian small and medium-sized enterprise. Asian Social Science, 10(2), 236-249. https://doi.org/10.5539/ass.v10n2p236

Ahmad, K., Teng, N. W., \& Zabri, S. M. (2017). The implementation of activity-based costing in Malaysian Small and Medium Sized Enterprises. Advanced Science letters, 23, 3170-3174. https://doi.org/10.1166/asl.2017.7692

Ajzen, L., \& Fishbein, M. (1980). Understanding attitudes and predicting social behavior. Prentice Hall Inc. Englewood Cliffs, NJ.

Al-Omiri, M., \& Drury, C. (2007). A survey of factors influencing the choice of product costing systems in UK organizations. Management Accounting Research, 18, 399-424. https://doi.org/10.1016/j.mar.2007.02.002

Anderson, S. W., \& Young, M. S. (1999). The impact of contextual and process factors on the evaluation of activity-based costing systems. Accounting Organizations and Society, 24(7), 525-559. https://doi.org/10.1016/S0361-3682(99)00018-5

Baird, K. M., Harrison, G. L., \& Reeve, R. C. (2004). Adoption of activity management practices: a note on the extent of adoption and the influence of organizational and cultural factors. Management Accounting Research, 15, 383-399. https://doi.org/10.1016/j.mar.2004.07.002

Beheshti, H. M. (2004). Gaining and sustaining competitive advantage with activity based cost management System. Industrial Management \& Data Systems, 104(5), 377-383. https://doi.org/10.1108/02635570410537462

Briciu, S., \& Căpuşneanu, S. (2010). "Effective cost analysis tools of the Activity-Based Costing (ABC) 
method", Annales Universitatis Apulensis, Series Oeconomica, 12(1), 25-35.

Brierley, J. A. (2009). An examination of the factors influencing thelLevel of consideration for activity-based Costing. International Journal of Business and Management, 3(8), 58-67. https://doi.org/10.5539/ijbm.v3n8p58

Byrne, S. (2011). What determines ABC success in mature sites? Journal of Accounting and Organizational Change, 7(3), 259-277. https://doi.org/10.1108/18325911111164204

Cagwin, D., \& Bouwman, M. J. (2002). The association between activity-based costing and improvement in financial performance. Management Accounting Research, 13, 1-39. https://doi.org/10.1006/mare.2001.0175

Chand, M., \& Dahiya, A. (2010), Application of management accounting techniques in Indian small and medium hospitality enterprises: An empirical study. International Journal of Entrepreneurship \& Small Business, 11(1), 25-41. https://doi.org/10.1504/IJESB.2010.034430

Chenhall, R. H. (2007). Theorizing contingencies in management control systems research. In Chapman, C., Hopwood, A. and Shields, M. (eds) Handbook of Management Accounting Research (Vol. 2). Elsevier.

Cooper, R., \& Kaplan, R. (1991). Profit priorities from activity based costing. Harvard Business Review. 69, $130-135$

Department of Statistics Malaysia. (2016). SME ANNUAL REPORT 2016/2017 Key Statistics on SMEs. Putrajaya.

Devine, K, Lammert, T., \& O’Clock, P. (2005). Product line and customer ROI: The next Generation of ABC. Management Accounting Quarterly, 7(1), 1-11.

Dubihlele, J., \& Rundoro, R. (2014). Employee training, managerial commitment and the implementation of activity based costing; impact on performance of SMEs. International Business \& Economics Research Journal, 13(1), 27-38.

Elhamma, A. (2012). The relationship between firm size, activity based costing and performance: an application on Moroccan enterprises. Journal of Accounting, Business and Management, 19(1), 90-102.

Elhamma, A., \& Zhang, Y. F. (2013). The relationship between activity-based costing, business strategy and performance in Moroccan enterprises. Accounting and Management Information System, 12(1), 22-38.

Faudziah, K., \& Rababah, L. (2011). Adoption and implementation of activity based costing system in Jordanian manufacturing companies. published at the International Business Information Management Conference (17th IBIMA). Milan, Italy.

Finke, A., \& Businska, L. (2011). TECHNOLOGY FOR LIGHT-WEIGHT ABC IN SME. http://isd.ktu.lt/it2011/material/Proceedings/4_ISS_8.pdf

Gunasekaran, A., Marri, H. B., \& Grieve, R. J. (1999.) Justification and implementation of activity based costing in small and medium sized enterprises. Logistics Information Management, 12(5), 386-394. https://doi.org/10.1108/09576059910295869

Hair, J. F., Black, W. C., Babin, B. J., \& Anderson, R. E. (2013). Multivariate Data Analysis (17 ${ }^{\text {th }}$ ed.). New Delhi: India. Pearson.

Hall, O. P., \& McPeak, C. J. (2011). Are SMEs ready for ABC? Journal of Accounting and Finance, 11(4), 11-22.

Hansen, S. C., \& Van der Stede, W. A. (2004). Multiple facets of budgeting: an exploratory analysis. Management Accounting Research, 15, 415-439. https://doi.org/10.1016/j.mar.2004.08.001

Hopper, T., Tsamenyi, M., Uddin, S., \& Wickramasinghe, D. (2009). Management Accounting in Less Developed Countries: What is known and Needs Knowing. Accounting, Auditing and Accountability Journal, 22(3), 469-514. https://doi.org/10.1108/09513570910945697

Ismail, M. F. Z., \& Reddy, K. (2017). Impact of Activity-based Costing (ABC) on competitive advantage in the Jordanian Telecommunication. Research Journal of Finance and Accounting, 8(20), 1-6.

Ismail, N. A., \& King, M. (2007). Factors influencing the alignment of accounting information systems in small and medium sized Malaysian manufacturing firms. Journal of Information Systems and Small Business, $l(1 / 2), 1-20$. 
James, P. C. (2013). An analysis of the factors influencing the adoption of activity based costing.

Khozein, A., \& Dankoob, M. (2011). Activity based costing system and its succeed implementing in organization. Australian Journal of Basic and Applied Sciences, 5(10), 613-619.

Kocakulah, M. C., Foroughi, A., Stott, A, \& Manyoky, L. (2017). Activity based costing: Helping small and medium sized firms achieve a competitive edge in the global marketplace. Journal of Accounting \& Marketing, 6(3), 1-9. https://doi.org/10.4172/2168-9601.1000245

Kraus, S., Harms, R., \&Schwarz, E. J. (2006). Strategic planning in smaller enterprises - new empirical findings. Management Research News, 29(6), 334-344. https://doi.org/10.1108/01409170610683851

Kulmala, H., Kajuter, P., \& Valkokari, K. (2007) Inter-organizational cost management in SME networks. Proceedings of the 8th Manufacturing Accounting Research Conference, Trento, Italy, June 18-20, 2007

Lou, Y., Wang, H. C., \& Lan, J. (2017). Design and implement the activity-based costing in Taiwan. Journal of Business and Management, 19(1), 41-46. https://doi.org/10.9790/487X-1901074146

Machado, M. (2012). 'Activity Based Costing Knowledge: Empirical study on small and medium size enterprises'. Revista Contemporânea de Contabilidade, 9(18), 167-186. https://doi.org/10.5007/2175-8069.2012v9n18p167

Maelah, R., \& Ibrahim, D. (2007). Factors influencing activity based costing (ABC) adoption in manufacturing industry. Investment Management and Financial Innovations, 4(2), 113-148.

Mahal, I., \& Hossain, M. A. (2015). Activity-Based Costing (ABC)-An effective tool for better management. Research Journal of Finance and Accounting, 6(4), 66-73.

Nair, S., \& Yee, S. N. (2017).Factors affecting management accounting practices in Malaysia. International Journal of Business and Management, 12(10), 177-184. https://doi.org/10.5539/ijbm.v12n10p177

Nandan, R. (2010). Management accounting needs of SMEs and the role of professional accountants: A renewed research agenda. JAMAR, 8(1), 65-78.

Pokorná, J. (2016), Impact of activity-Based costing on financial performance in the Czech Republic. Acta Universitatis Agriculturae et Silviculturae Mendelianae Brunensis, 64(2), 643-652. https://doi.org/10.11118/actaun20166402064

Quinn, M., Elafi, O., \& Mulgrew, M. (2017). "Reasons for not changing to activity-based costing: a survey of Irish firms". PSU Research Review, 1, 63-70. https://doi.org/10.1108/PRR-12-2016-0017

Ríos, M., Colomina, C., \& Rodríguez-Vilariño, M. L. (2014). Is the activity based costing system a viable instrument for small and medium enterprises? The case of Mexico. Estudios Gerenciales, 30(132), 220-232. https://doi.org/10.1016/j.estger.2014.02.014

Sekaran. (2006). Research Methods for Business: A skill building approach (4th ed.). US: Wiley.

Sohal, A. S., \& Chung, W. W. C. (2011). Costing systems in transition: a review of recent developments. Management Accounting, 68(1), 38-42.

$\mathrm{Xu}, \mathrm{L}$. (2012). Implementation of activity-based costing in China: a case study of a Chinese multinational company. Master of Accountancy research thesis, School of Accounting and Finance, University of Wollongong. Available from: http://ro.uow.edu.au/thesis/3613 [accessed 23 September 2013].

Yapa, P., \& Konchange, P. (2012). Factors influencing the implementation of activity-based costing in Thailand: a case study of a Thai telecommunications company. Journal of Performance Management, 1, 1-24.

Zhang, Y. F., \& Isa, C. R. (2010). Factors influencing activity-based costing Success: A Research Framework. International Journal of TRADE, Economics and Finance, 1(2), 144-150. https://doi.org/10.7763/IJTEF.2010.V1.26

\section{Copyrights}

Copyright for this article is retained by the author(s), with first publication rights granted to the journal.

This is an open-access article distributed under the terms and conditions of the Creative Commons Attribution license (http://creativecommons.org/licenses/by/4.0/). 